\title{
Comparison of Field Crops with Tap and Fibrous Root System at Early and Late Growth Stages
}

\begin{abstract}
Hayati Akman ${ }^{1, a, *}$
${ }^{I}$ Department of Seed Technology, Sarayönü Vocational School, Selçuk University, 42430 Konya, Turkey *Corresponding author

A R T I C L I N F O A B S T R A C T

Research Article

Knowledge of root architecture is significant since it influences on pathways from, photosynthesis products, water and nutrient movement. This study purposed to elucidate root mass, root length, root/shoot ratio, root/total mass ratio and above-ground characteristics in Vicia pannonica Crantz., Carthamus tinctorius L. and Pisum sativum ssp. arvense L. with taproot and Triticum aestivum L., Hordeum vulgare L. conv. distichon, X Triticosecale Wittmack, Avena sativa L. and Secale cereale L. with fibrous roots at $200 \mathrm{~cm}$ long tubes under field-grown condition. Crop harvesting is based on early and late growth stages of cereal crops. The results indicated that winter field crops had a wide range of differences with regard to root and above-ground traits at both growth stages. The root traits of field crop species varied considerably from 0.3 to $5.9 \mathrm{~g}$ and 2.4 to $11.9 \mathrm{~g}$ for root mass and 84.7 to $127.7 \mathrm{~cm}$ and 84.5 to $166 \mathrm{~cm}$ for root length at early and late growth stages respectively,

Keywords:

Winter crop species

Fibrous and tap

Root system

Shoot

Development stage of root mass accumulated in $0-20 \mathrm{~cm}$ root length at early and late growth stages, ranged between 52.3 to $81.4 \%$ and 27.7 to $75.2 \%$, respectively. The findings showed that crops with taproot had less root and shoot mass and shorter root length than cereals with fibrous roots at both growth stages. This study also significantly advances our understanding of root-shoot competition by comparing the agronomical traits of winter field crops with tap and fibrous roots at different growth stages.
\end{abstract}

hayatiakman@selcuk.edu.tr (iD)https://orcid.org/0000-0001-6878-3329

(c) (1) (9) This work is licensed under Creative Commons Attribution 4.0 International License

\section{Introduction}

Field crops including winter cereals, pea, vetch and safflower are mainly grown for human food and livestock feed as well as cover crops (Schonbeck and Morse, 2006; Bodner et al., 2010). Winter field crops are well known for producing high yields in comparison to their spring planted cultivars because they consumed more water and nutrient for productivity due to high precipitation during long vegetation stages. In these periods, their root system has great importance for biological activity, aggregate stability and hydraulic properties to develop soil traits (Bodner et al., 2010). Bio-drilling has been recently suggested as used in the rotation of deep-rooted species with taproot especially no-tilling farming to minimize soil compaction and create pathways with low resistance for succeeding crops (Cresswell and Kirkegaard, 1995).

It was reported that yield depended on all the growth patterns such as shoot, soil and root traits, however water and nutrient uptake are mainly related to the rooting modules (Ruget et al., 2002; Smit and Groenwold, 2005). Proceeding of high root activity in legume and cereal crops is mainly dependent upon plant type or canopy traits (Osaki et al., 1997).

A long root system leads to increase root respiration in relation to high energetic costs and is not always fundamental for the plant (Lynch and Beebe, 1995), though, root system size has a relationship with grain yield (Heřmanská et al., 2015). Therefore, it is highly important to understand balance and relationship between plant root and shoot growth as well as physiological and agronomical traits. Growth balance in plant root and shoot is frequently considered to be an important trait of phenotypic plasticity in plant response to the environment (Robinson et al., 2010). However, root system studies on plant species and/or genotypes are insufficient since they are laborious and slow (Adu et al., 2014). When root studies are also conducted with artificial media in laboratory and greenhouse, actual plant growth parameters may not correspond as response to all possible interactions between investigated traits. (Rich and Watt, 2013). 
This study targeted to understand and compare root and shoot growth parameters of different winter field crops with tap and fibrous roots in long tubes filled with field soil under field-grown condition.

\section{Materials and methods}

\section{Experimental Site}

The study was conducted in Sarayonu district, Central Anatolian Region, Turkey in 2014 and 2015 vegetation period. The research field is located at Sarayonu district where its altitude is 1061 above mean sea level. The weather graph is given in Figure 1.

\section{Plant Materials and Field Experiment}

In the study, eight winter field crops such as two rowedbarley (cv. Larende), oat (cv. Seydişehir), triticale (cv. Tatlicak), rye (cv. Aslim), bread wheat (cv. Konya 2002) with a fibrous root system and safflower (cv. Balc1), forage pea (cv. Özkaynak) and Hungarian vetch (cv. unknown) with the taproot system were used. Seedlings were grown into cylindrical PVC tubes with $12 \mathrm{~cm}$ in diameter and 200 $\mathrm{cm}$ in depth. The long tubes filled with field soil were installed to 2-meter depth. Planting was carried out on November 12, 2014 and a single plant for each species per tube was grown.

Plants were well-watered before sowing and fertilized as top-dressed with the fertilizer, DAP including $46 \% \mathrm{P}_{2} \mathrm{O}_{5}$ and $18 \% \mathrm{~N}\left(130 \mathrm{~kg} \mathrm{ha}^{-1}\right)$ together with sowing. In spring, plants were well-watered at stem elongation (GS31) according to Zadoks scale (Zadoks et al., 1974) by sprinkler irrigation system with a solution including humic acid $(3.5 \mathrm{ml})$ and $17 \mathrm{~g}$ urea $(46 \% \mathrm{~N})$.

Soil samples were analyzed for some parameters. The soil was clay-loam, clay-loam-sandy with low organic matter (1.5\%) and a high level of $\mathrm{CaCO}_{3}(19.2 \%)$. Inorganic $\mathrm{N}$ content was $43.0 \mathrm{mg} / \mathrm{kg}$, $\mathrm{pH}$ was 8.0 and no salinity problems have been observed.

\section{Harvesting and Measurements}

Harvesting and measurements of roots were studied at cereal stem elongation stage (GS 31) and milk stage (GS 75-83; June 10, 2015) according to Zadoks scale (Zadoks et al., 1974). Firstly, shoot traits were measured and harvested and then washed roots with pressurized water were measured to find out the longest root as maximum root length on a flat. Roots were cut to five parts in $20 \mathrm{~cm}$ length up to $80 \mathrm{~cm}$ as well as a remaining part and weighted separately. To record root and shoot dry mass, tissues were hold for 48 hours at $80^{\circ} \mathrm{C}$. Root mass percentage in each root length was found by root mass distribution

\section{Statistical Analysis}

The data were analysed in the MSTAT-C statistical software (Mstatc, 1991) in randomized complete block design with three replications. Differences between means were assessed to find out significance levels with the LSD test.

\section{Results and discussion}

The study indicated that there were statistically significant differences among the field crop species for the shoot and root traits. Data in relation to root and shoot traits of winter field crops at early and late growth stages are given at Figures and Table 1.

\section{Root Traits of Field Crops at Different Growth Stages}

The root length of field crops varied from 84.7 to 127.7 $\mathrm{cm}$ at the early growth stage, while it ranged from 84.5 to $166 \mathrm{~cm}$ at the late growth stage (Figure 2 and 3). Hungarian vetch and pea had the shortest root length at the stem elongation stage, however cereals showed higher root length. At the late growth stage, Hungarian vetch had minimum root length, however the root length of cereals was comparatively higher than other field crops. The results presented here were consistent with findings of earlier study indicating that pea had shallow root system compared to other field crops (Reid et al., 1987). But, in the study, Hungarian vetch had shallow root length at the seedling stage as well as pea, while its root length at the late growth stage was the lowest. Furthermore, a study conducted by minirhizotron measurement showed that pea had one of the shortest root systems among spring sowing safflower, sunflower, wheat, crambe, canola, soybean and common bean (Merrill et al., 2002).

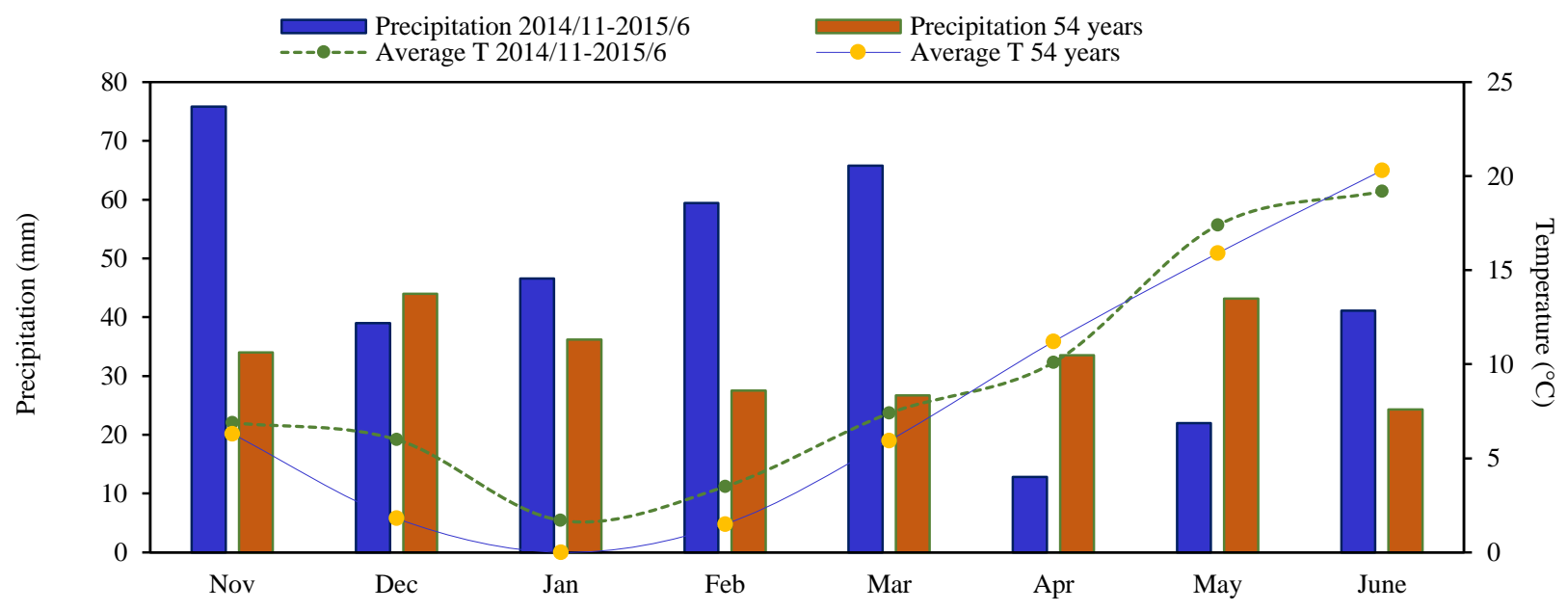

Figure 1. Precipitation (bars) and temperature (lines) in 2014-2015 (blue bars and lines) and long term (54 years) mean (read bars and lines) in Konya Meteorology Station. 
Table 1. Proportion (\%) of the roots in the $0-20 \mathrm{~cm}, 0-40 \mathrm{~cm} .0-60 \mathrm{~cm}$ and $0-80 \mathrm{~cm}$ root length presenting in each root segment at different growth stages

\begin{tabular}{|c|c|c|c|c|}
\hline \multirow{2}{*}{ Field crops } & \multicolumn{4}{|c|}{ Early growth stage } \\
\hline & $0-20$ & $0-40$ & $0-60$ & $0-80$ \\
\hline Barley & $71.1^{\mathrm{abc} * *}$ & $81.8^{\mathrm{a}-\mathrm{d}^{*}}$ & $90.4^{\mathrm{ab}^{*}}$ & $97.1^{1^{*}}$ \\
\hline Oat & $67.1^{\mathrm{abc}}$ & $77.4^{\mathrm{bcd}}$ & $87.7^{\mathrm{b}}$ & $96.3^{\mathrm{a}}$ \\
\hline Triticale & $75.8^{\mathrm{ab}}$ & $86.6^{\mathrm{abc}}$ & $91.2^{\mathrm{ab}}$ & $95.8^{\mathrm{a}}$ \\
\hline Rye & $73.0^{\mathrm{ab}}$ & $81.3^{\mathrm{a}-\mathrm{d}}$ & $88.4^{\mathrm{ab}}$ & $93.8^{\mathrm{a}}$ \\
\hline Wheat & $57.9^{\mathrm{bc}}$ & $74.8^{\text {cd }}$ & $93.4^{\mathrm{ab}}$ & $96.0^{\mathrm{a}}$ \\
\hline Pea & $52.6^{\mathrm{c}}$ & $69.6^{\mathrm{d}}$ & $76.7^{\mathrm{c}}$ & $86.1^{\mathrm{b}}$ \\
\hline Hungarian vetch & $52.3^{\mathrm{c}}$ & $92.8^{\mathrm{a}}$ & $97.5^{\mathrm{a}}$ & $99.3^{\mathrm{a}}$ \\
\hline Safflower & $81.4^{\mathrm{a}}$ & $89.7^{\mathrm{ab}}$ & $97.4^{\mathrm{a}}$ & $99.6^{\mathrm{a}}$ \\
\hline CV (\%) & 12 & 9.21 & 6.15 & 4.09 \\
\hline \multirow[t]{2}{*}{ LSD } & 19.4 & 13.2 & 9.74 & 6.83 \\
\hline & \multicolumn{4}{|c|}{ Late growth stage } \\
\hline Barley & $64.3^{\mathrm{ab}^{* * *}}$ & $74.5^{\mathrm{ab}^{* * *}}$ & $88.8^{\mathrm{a}^{*}}$ & $96.1^{1^{*}}$ \\
\hline Oat & $39.6^{\mathrm{cd}}$ & $54.0^{\mathrm{bc}}$ & $61.3^{\mathrm{b}}$ & $69.7^{\mathrm{c}}$ \\
\hline Triticale & $68.9^{\mathrm{a}}$ & $73.1^{\mathrm{ab}}$ & $78.2^{\mathrm{ab}}$ & $80.4^{\mathrm{abc}}$ \\
\hline Rye & $43.7^{\mathrm{bcd}}$ & $55.3^{\mathrm{bc}}$ & $61.9^{\mathrm{b}}$ & $72.7^{\mathrm{bc}}$ \\
\hline Wheat & $61.9^{\mathrm{abc}}$ & $70.0^{\mathrm{ab}}$ & $76.6^{\mathrm{ab}}$ & $90.0^{\mathrm{ab}}$ \\
\hline Pea & $75.2^{\mathrm{a}}$ & $80.0^{\mathrm{a}}$ & $85.1^{\mathrm{a}}$ & $96.5^{\mathrm{a}}$ \\
\hline Hungarian vetch & $27.7^{\mathrm{d}}$ & $46.6^{c}$ & $63.4^{\mathrm{b}}$ & $76.2^{\mathrm{bc}}$ \\
\hline CV (\%) & 16.83 & 14.35 & 13.98 & 12.79 \\
\hline LSD & 22.86 & 23.18 & 18.31 & 18.91 \\
\hline
\end{tabular}
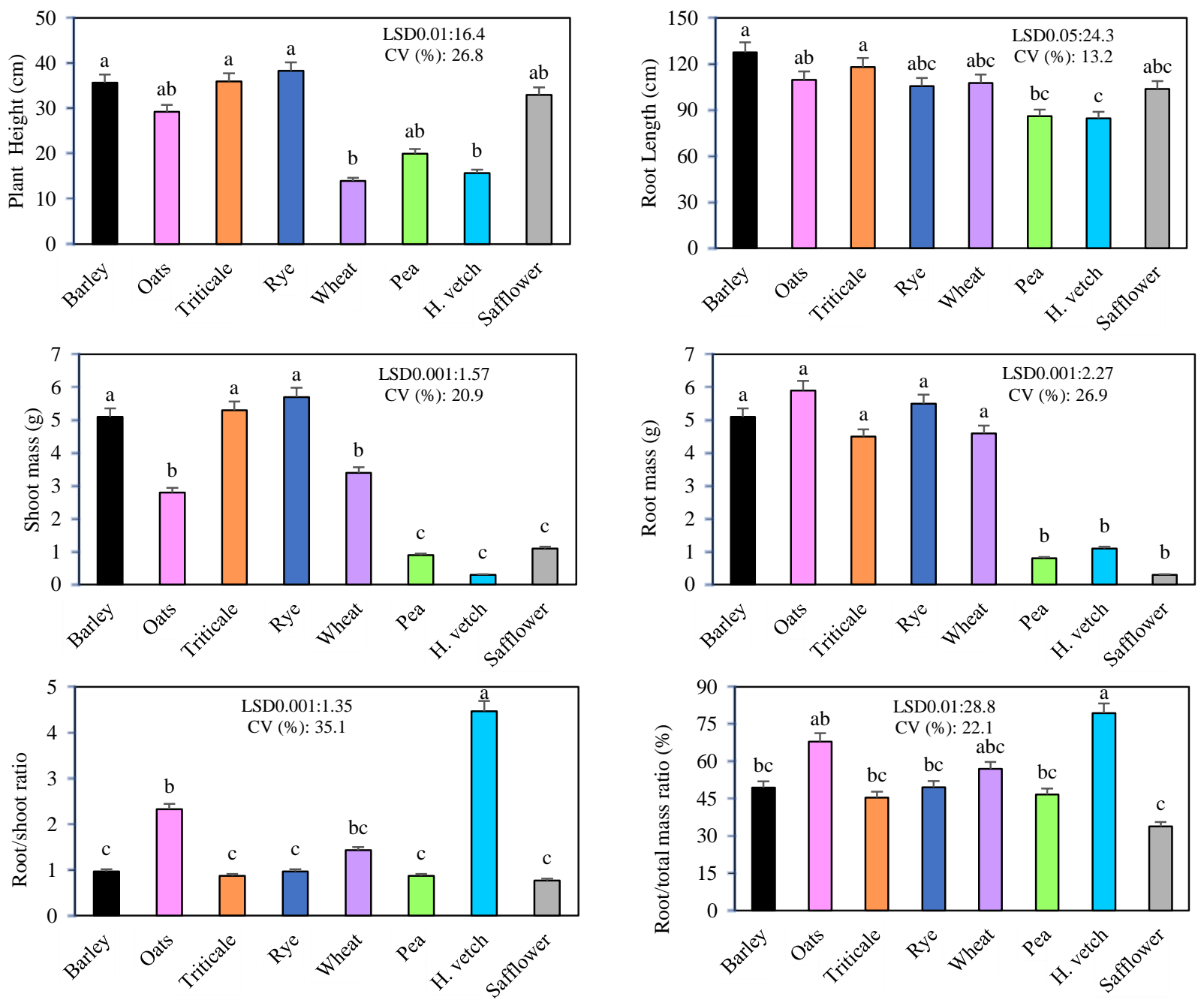

Figure 2. Root and shoot traits of winter field crops at early growth stage 

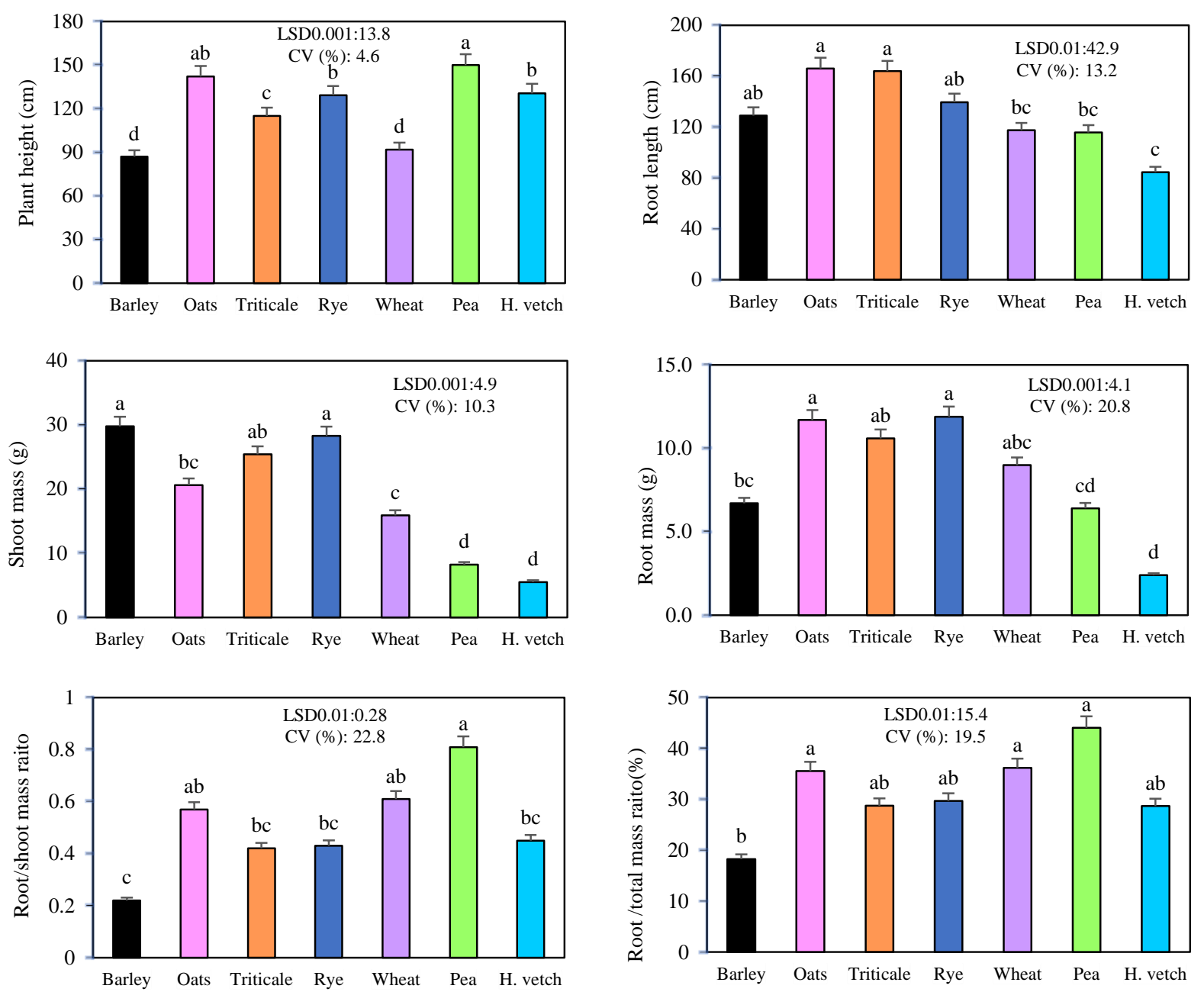

Figure 3. Root and shoot traits of winter field crops at late growth stage
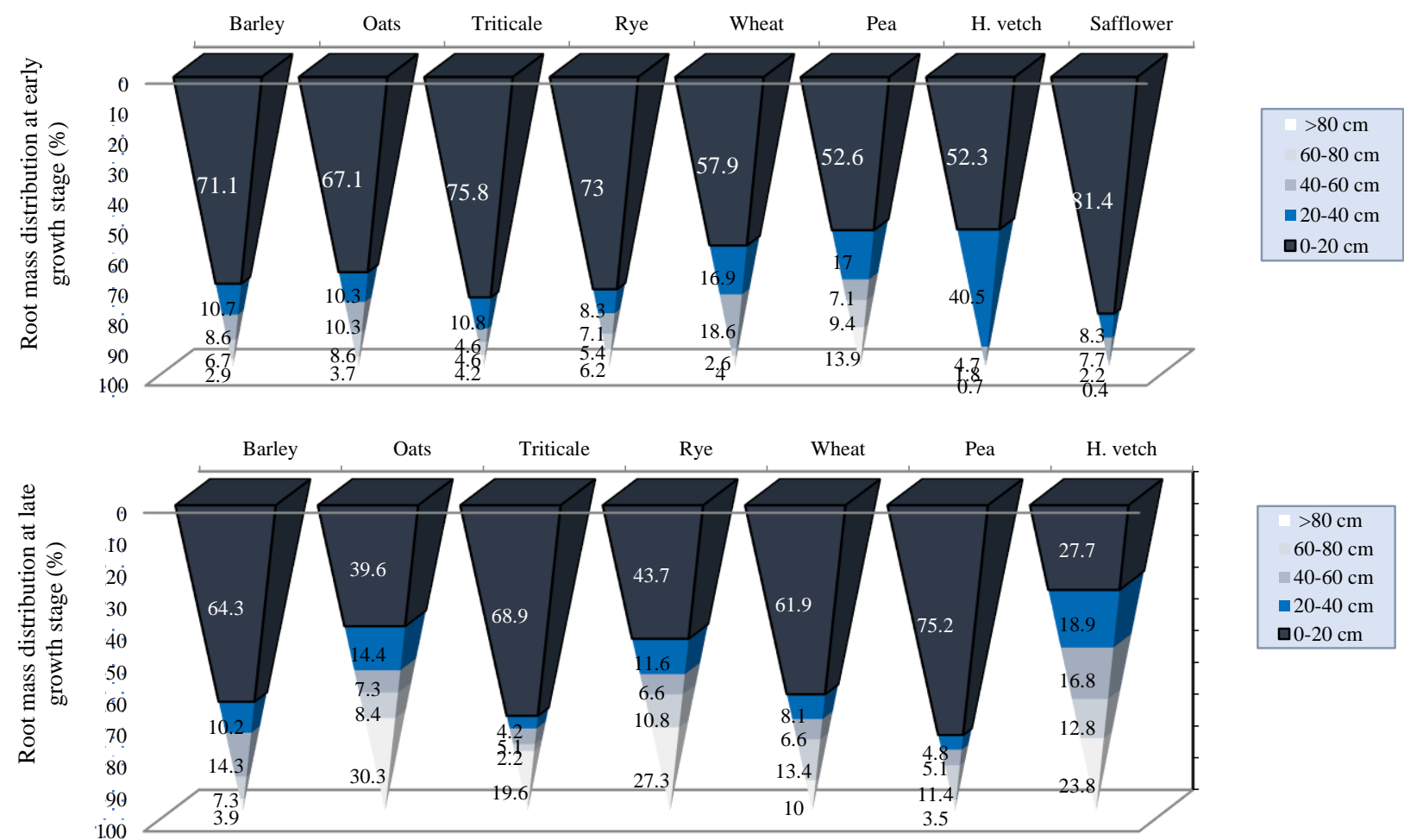

Figure 4. Root mass distribution in different root lengths of winter field crops at early and late growth stage 
Thorup-Kristensen (1998) indicated that the rooting depth of pea genotypes varied from 110 to $120 \mathrm{~cm}$, much higher than that of early genotype with $78 \mathrm{~cm}$. Furthermore, rooting depth of winter-sown pea varied between $88 \mathrm{~cm}$ and $106 \mathrm{~cm}$ according to February measurement (Vocanson et al., 2006). However, root depth in spring sown pea penetrated up to $70 \mathrm{~cm}$ in the field using the trench wall technique (Voisin et al., 2002). Here, root length of pea was $86 \mathrm{~cm}$ at the seedling stage, but it was $115.7 \mathrm{~cm}$ at the late growth stage (Figures 2 and 3). A research conducted by Bonachela (1996) to compare barley and triticale species indicated similar results with the findings of the study so that triticale root growth increased more between early and late growth stages than barley and its root reached up to 90 and $180 \mathrm{~cm}$ depending on wetting depth. Root lengths of barley and wheat were reported to reach from 150 to $290 \mathrm{~cm}$ and 150 to $300 \mathrm{~cm}$, respectively under optimum growth condition (Borg and Grimes, 1986). The findings of this study at the late growth stage were under those ranges. According to results, the root length of barley and Hungarian vetch between early and late growth stages were unchanged considerable, but root length of triticale, oat and pea increased highly.

A close look at the data in Figures 2 and 3 in field crops showed a wide range of differences in terms of the root mass. It ranged from 0.3 to $5.9 \mathrm{~g}$ at the early growth stage and 2.4 to $11.9 \mathrm{~g}$ at the late growth stage. Based on the results of the current study, cereals with fibrous root had more root mass than field crops with taproot at both growth stages. Root mass is highly related to the size of a root system (Ehdaie et al., 2010). At the early growth stage, there are no significant differences among the cereal crops and took part in the same group (Figure 2), while the mass of barley with less root mass at the late growth stage took part in the top among cereals (Figure 3). Chen and Weil (2010) compared root and shoot traits of forage radish and rapeseed with taproot and rye with fibrous root in the field. They found that there were no significant differences in terms of their root mass, but significant for shoot mass in no compaction. Their findings are inconsistent with our results. The differences between findings may result from variation of their growth periods, planting in late August and as well as sampling after three months as cover crops. In the present work, the root mass of cereals and Hungarian vetch was bent almost double between early and late growth stages, however the root mass of pea increased eight-fold.

Significant differences in the root/shoot ratio of mass were found among the field crops. The results here confirmed the results of Campbell et al. (2000) who indicated that root/shoot ratios varied between crop species. This comparative experimental approach showed that the root/shoot ratio of field crops varied from 0.77 to 4.47 at the early growth stage and 0.22 to 0.81 at the late growth stage. Superior plant growth and development are proceed to the maintenance of a balance between root and shoot growth and furthermore, there are wide differences among species with regard to root-shoot ratios (Kramer and Boyer, 1995). Roots depend on sugar and hormonal growth regulators produced in shoots, while shoots need the water and nutrients from roots (Kozlowski, 1971). Since crop roots may use more than $50 \%$ of daily photosyntetic products (Lambers et al., 2002; Ciaglo-Androsiuk, 2012), it is a significant growth balance between root and shoot to reach the potential yield. The root/shoot ratio of field crops was significantly reduced at the late growth stage compared to the early growth stage, but the reduction in that of pea was slightly low. Gan et al. (2009) studied root and shoot development in seven field crops at five different growth stages. They indicated that root growth was more rapid compared to shoot mass at early growth stage and root/shoot ratio reduced as crop matured. The results presented here are in accordance with Siddique et al. (1990) who reported that root: shoot ratios of wheat varieties decreased with crop growth stage and varied from 0.52 to 0.64 at anthesis. The most reduction of root/shoot ratio between two growth stages was observed in Hungarian vetch since the increase of shoot mass was greater than the root mass.

The results presented here suggested that root/total mass ratio ranged from 33.9 to $79.4 \%$ at the early growth stage and 18.3 to $44.1 \%$ at the late growth stage. Root mass proportion into the total mass of field crops at the late growth stage was low compared to the early growth stage. The results were convenient with reference to Gan et al. (2009), suggesting the proportion of root mass in total mass reduced with crop growth stages. They also indicated that a reduction in root/total mass ratio was more substantial in oilseeds and pulses than in wheat. In this study, a decrease in root mass in total mass was highly significant in barley and Hungarian vetch, but quite minimum in pea.

\section{Root Mass Distribution in Different Root Lengths of} Field Crops

The results for the root mass distribution (RMD) are shown in Table 1 and Figure 4. The differences between root mass in root length at $0-20 \mathrm{~cm}, 0-40 \mathrm{~cm}, 0-60 \mathrm{~cm}$ and $0-80 \mathrm{~cm}$ of field crops for early and late growth stages were regarded considerably (Table 1 ). In the study, root mass distribution per root length of field crops at early growth stage was found from 52.3 to $81.4 \%$ in $0-20 \mathrm{~cm}$ root length, 69.6 to 92.8 in $0-40 \mathrm{~cm}, 76.7$ to $97.5 \%$ in 0 $60 \mathrm{~cm}$ and 86.1 to $99.6 \%$ in $0-80 \mathrm{~cm}$, while it varied from 27.7 to $75.2 \%$ in $0-20 \mathrm{~cm}, 46.6$ to $80 \%$ in $0-40 \mathrm{~cm}, 61.3$ to $88.8 \%$ in $0-60 \mathrm{~cm}$ and 72.7 to 96.1 in $0-80 \mathrm{~cm}$ at late growth stage (Table 1). Increase rate in root mass of pea in $0-20 \mathrm{~cm}$ root length was the most among the field crops between early and late growth stages. The study revealed that RMD of pea at the early growth stage was low in the top layer, however safflower possessed the highest RMB. Besides, at the late growth stage, due to differences in the increase rate of root mass and root length, pea had the highest root mass in $0-20 \mathrm{~cm}$ root length contrary to at early growth stage, but the lowest RMD was obtained from Hungarian vetch. The results confirmed findings of Gregory et al. (1978) who reported $65 \%$ of root mass in barley and wheat was found in $0-30 \mathrm{~cm}$ of soil. Also, in agreement with the findings, Hurd and Spartt (1975) and Lotfollahi (2010) showed root mass below $60 \mathrm{~cm}$ remained constant after reaching a maximum. In here, root mass at $20 \mathrm{~cm}$ and $40 \mathrm{~cm}$ root length increased slightly depending on crop species at different growth stages, however it almost doubled in Hungarian vetch (Figure 4). Additionally, 0.4 to $13.9 \%$ at the early growth stage and 3.5 to $30.3 \%$ of the late growth stage of root mass were constituted below $80 \mathrm{~cm}$. 


\section{Plant Height and Shoot Mass of Field Crops at Early and Late Growth Stages}

The study results showed that there were statistically significant differences among the field crops in terms of plant height at both growth stages. Their plant height varied from 14 to $38.3 \mathrm{~cm}$ at the early growth stage and 92 to 150 $\mathrm{cm}$ at the late growth stage (Figures 2 and 3). Hungarian vetch and wheat had the shortest plant height at the early growth stage. At the late growth stage, maximum plant height was observed in pea and oat, while minimum data was obtained from barley and wheat. The increase in plant height of pea and Hungarian vetch was greater than that in cereal crops. Safflower with short plant height did not compete with field crops with regard to plant height, therefore it was not able to obtain any data for the late growth stage. However, pea and Hungarian vetch had the capacity to compete with cereal crops. In a prevous study, Barraclough et al. (1991) showed plants with longer plant height had not short root, which is in accordance with wheat and barley at the late growth stage, but not for pea had the longest plant height and shorter root length compared to other field crops.

Shoot mass significantly differed in different species, varying from 0.3 to $5.7 \mathrm{~g}$ at the early growth stage and 5.5 to $29.8 \mathrm{~g}$ at the late growth stage (Figures 2 and 3). Cereals with fibrous root showed high shoot mass compared to crops with taproot at both growth stages. In addition, the study indicated that Hungarian vetch had minimum shoot mass. Previous studies reported that crops with high shoot mass had greater root mass in wheat under favourable condition (Atta et al., 2013) in forage pea and vetch (Bilgili et al., 2011). The results presented here were in accordance with those studies so that crops with taproot and low shoot mass were not high on root mass as opposed to cereals with the fibrous root at both growth stages. Moreover, the increase in shoot mass between early and late growth stages was low in crops with a taproot, however their increase percentage was higher than cereals.

\section{Conclusions}

Root measurements had difficulty to evaluate under field weather condition. There is also limited data to compare the root traits of different winter crops. In the present study, field crops were grown into field soil and in long tubes $(200 \mathrm{~cm})$. The findings showed that cereals with the fibrous root at early and late growth stages possessed significantly higher root mass than pea, Hungarian vetch and safflower with a taproot. In addition, the root length of cereals was generally higher than pea and Hungarian vetch at both growth stages. The experiments performed here clearly demonstrated that a significant rate of root mass was concentrated in $0-20 \mathrm{~cm}$ root length. Moreover, root/shoot and root/total mass ratios at the early growth stage of field crops were lower as opposed to the late growth stage. At the early and late growth stage, differences in root and shoot growth varied to depending on the species. Twogether, these results will provide a comprehensive understanding of root and shoot growth at early and late developmental growth stages of winter field crops with tap and fibrous root.

\section{References}

Adu MO, Chatot A, Wiesel L, Bennett MJ, Broadley MR, White PJ, Dupuy LX. 2014. A scanner system for high-resolution quantification of variation in root growth dynamics of Brassica rapa genotypes. J. Exper. Botany, 65: 39-2048.

Atta BM, Mahmood T, Trethowan RM. 2013. Relationship between root morphology and grain yield of wheat in northwestern NSW, Australia. Aust. J. Crop Sci., 7: 2108-2115.

Barraclough PB, Weir A.H, Kuhlmann H. 1991. Factors affecting the growth and distribution of winter wheat roots under UK field conditions. Developments in Agricultural and Managed-Forest Eco., 24: 410-441.

Bilgili U, Çarpıcı EB, Aşık BB, Çelik N. 2011. Root and shoot response of common vetch (Vicia sativa L.), forage pea (Pisum sativum L.) and canola (Brassica napus L.) to salt stress during early seedling growth stages. Tur. J. Field Crops. 16: 33-38.

Bodner G, Himmelbauer M, Loiskandl W, Kaul HP. 2010. Improved evaluation of cover crop species by growth and root factors. Agronç Sustain. Dev., 30: 455-64.

Bonachela S. 1996. Root growth of triticale and barley grown for grain or for forage-plus-grain in a Mediterranean climate. Plant and Soil. 183: 239-251.

Borg H, Grimes D.W. 1986. Depth development of roots with time-an empirical description. Trans. Asae., 29: 194-197.

Campbell CA, Zentner RP, Liang BC, Roloff G, Gregorich EC, Blomert B. 2000. Organic C accumulation in soil over 30 years in semiarid southwestern Saskatchewan-effect of crop rotations and fertilizers. Canadian Journal of Soil Sci. 80: 179-192.

Chen G, Weil RR. 2010. Penetration of cover crop roots through compacted soils. Plant and Soil, 331: 31-43.

Ciaglo-Androsiuk S. 2012. Relationship between root and yield related morphological characters in Pea (Pisum sativum L.). Plant Breeding and Seed Sci. 66: 3-15.

Cresswell HP. Kirkegaard JA. 1995. Subsoil amelioration by plant roots - the process and the evidence. Aust. J. Soil Res., 33: 221-239.

Ehdaie B, Merhaut DJ, Ahmadian S, Hoops AC, Khuong T, Layne AP, Waines JG. 2010. Root system size influences water-nutrient uptake and nitrate leaching potential in wheat. Agronomy and Crop Sci., 196: 455-466.

Gan YT, Campbell CA, Janzen HH, Lemke R, Liu LP, Basnyat P, McDonald CL. 2009. Root mass for oilseed and pulse crops: growth and distribution in the soil profile. Canadian Journal of Plant Sci., 89: 883-893.

Gregory PJ, McGowan M, Biscoe PV, Hunter B. 1978. Water relations of winter wheat: 1. growth of the root system. J. Agr. Sci., 91: 91-102.

Heřmanská A, Středa T, Chloupek O. 2015. Improved wheat grain yield by a new method of root selection. Agron. for Sust. Dev., 35: 195-202.

Hurd EA, Spartt ED. 1975. Root patterns in crops as related to water and nutrient uptake. In Physiological aspects of dry land farming. (Ed US Gupta) pp. 167-235. (Oxford IBH: New Dehli, India).

Kramer PJ, Boyer JS. 1995. Water relations of plants and soils. Academic press.

Kozlowski TT. 1971. Growth and development of trees. Volume I: Seed germination, ontogeny and shoot growth. Growth and development of trees. Volume I: Seed germination, ontogeny and shoot growth. Academic Press. Newyork\& London.

Lambers H, Atkin O, Millenaar FF. 2002. Respiratory patterns in roots in relation to their functioning. In: Y. Waisel, Eshel A., Kafkaki K. (ed.): Plant roots, the hidden half. 521-552.

Lotfollahi MA. 2010. Wheat root length density as affected by nitrogen treatment. World Congress of Soil Science, Soil Solutions for a Changing World, 1-6 August 2010, Brisbane, Australia. 
Lynch JP, Beebe SE. 1995. Adaptation of bean (Phaseolus vulgaris L.) to low phosphorus availability. HortScience, 30: $1165-1171$

Merrill SD, Tanaka DL, Hanson JD. 2002. Root length growth of eight crop species in haplustoll soils. Soil Sci. Soc. Am. J. 66: 913-923.

Mstatc 1991. Michigan State University. Wast Lansing, Michigan, USA.

Osaki M, Shinano T, Matsumoto M, Zheng T, Tadano T. 1997. A root-shoot interaction hypothesis for high productivity of field crops. Soil Science and Plant Nutrition, 43: 1079-1084.

Reid JB, Shekell G, Kraft JM, Scott RE. 1987. Subsoil conditions and maximum rooting depths of commercial pea crops grown in Canterbury, New Zealand. New Zealand J. Agr. Resear., 30: 27-33.

Rich SM, Watt M. 2013. Soil conditions and cereal root system architecture: review and considerations for linking Darwin and Weaver. J. Exper. Botany, 64: 1193-1208.

Robinson D, Davidson H, Trinder C, Brooker R. 2010. Rootshoot growth responses during interspecific competition quantified using allometric modelling. Annals of Botany, 106: 921-926.
Ruget F, Brisson N, Delecolle R, Faivre R. 2002. Sensitivity analysis of a crop simulation model, STICS, in order to choose the main parameters to be estimated. Agronomie, 22: 133-158.

Schonbeck M, Morse R. 2006. Using manually-operated seeders for precision cover crop plantings on the small farm. virginia association for biological farming information sheet. Accessed at: http://www.vabf.org/pubs.php.

Siddique KHM, Belford RK, Tennant D. 1990. Root: shoot ratios of old and modern, tall and semi-dwarf wheats in a Mediterranean environment. Plant and Soil, 121: 89-98.

Smit AL, Groenwold J. 2005. Root characteristics of selected field crops: data from the Wageningen Rhizolab (19902002). Plant and Soil, 272: 365-384.

Thorup-Kristensen K. 1998. Root growth of green pea (Pisum sativum L.) genotypes. Crop Sci., 38: 1445-1451.

Vocanson A, Jeuffroy M.H, Roger-Estrade J. 2006. Effect of sowing date and cultivar on root system development in pea (Pisum sativum L.). Plant and Soil, 283: 339-352.

Voisin A.S, Salon C, Munier-Jolain N.G, Ney B. 2002. Effect of mineral nitrogen on nitrogen nutrition and mass partitioning between the shoot and roots of pea (Pisum sativum L.). Plant and Soil, 242: 251-262.

Zadoks J.C, Chang T.T, Konzak C.F. 1974. A decimal code for the growth stages of cereals. Weed Research, 14(6): 415-421. 